\title{
PROFITABILITY AND VIABILITY ANALYSES OF SMALL-HOLDER COCOA PRODUCTION THREE MANAGEMENT SYSTEMS IN ABIA STATE NIGERIA: A STUDY FOR COMMERCIALIZATION IMPLICATIONS
}

\author{
*ONWUMERE, J., AND **NJOKU, M.E \\ *Department of Agribusiness and Management \\ **Department of Marketing, Michael Okpara University of Agriculture, \\ Umudike, PBM 7267, Umuahia Abia State Nigeria \\ *Email: meetingjoe@yahoo.com
}

\begin{abstract}
The study examined the viability of small-holder cocoa production under three management systems in Abia State. The systems studied were owner-, lease and sharecrop management systems. The instrument of data collection was questionnaire. Using a random selection method 150 cocoa farmers were selected for the study. The data collected were analyzed using descriptive statistics, Benefit Cost Ratio and Net Present Value at 10\% discount rate. Results show that cocoa production is profitable and viable in the study area. Also, the three management systems are efficient and practicable. The NPV for owner managed was highest showing that it is the most economically viable management system. It is recommended that ample amount of capital therefore should be invested into cocoa production to reinvigorate life in this dying and critically dwindling commercialized sector. Thus government and multinationals should assist the cocoa farmers with soft loans to encourage them help enhance production and break even. Moreso, group production should be encouraged in the study area for commercialization purposes considering the fact that cocoa production option is viable and profitable.
\end{abstract}

Key words: Profitability, Viability, Cocoa, Management, Systems

\section{INTRODUCTION}

Cocoa belongs to the family steruliacacea and genus "Theobroma". It was discovered in the $18^{\text {th }}$ century at the Amazon basin and later spread to other tropical areas of South and Central America (Asun 2001). The crop was eventually introduced in Nigeria in 1887 (Ayorinde).Nigeria as a developing country had long ago commercialized her cocoa production and was rated the second highest producer of cocoa in world ranking until 1971 when its export declined to 216000 and 150000 metric tonnes in 1986 thus, reducing the countries market share to about 6\% and to the fifth largest producer till date (Oyinloye 1999). Presently, Nigeria is rated as fourth largest world producer of cocoa with about 385, 000 metric tonnes per annum, an increase of 215,000 metric tonnes from year 2000 production level (Erelu, 2008). By these ratings, Nigeria competed favourably with other front liners in cocoa industry like Ivory Coast, Indonesia and Ghana. Prior to the oil boom of the mid-70s cocoa was one of the highest foreign exchanged earners in Nigeria and for a long time the crop has been generating substantial foreign earnings for the country (Titola 1997). The cocoa sector still offers a large sizable number of people employments both directly and indirectly (Oduwole 2004). Small holder farmers (less than 5ha) grow cocoa which generates work opportunities for an estimated 10.5 million Africans. In Nigeria an average small scale farmer generates less than 5 bags (roughly $300 \mathrm{~kg}$ per hectare) per season. Considering return to investment and production capacity, Ondo State farmers are rated the highest in Nigeria (Oluyole, 2005). In addition, it is an important source of raw material and revenue to government of cocoa producing states. 
However evidence has shown that the return performance from cocoa production in recent years has been declining. This may be due to export capacity reduction in the industry and a number of other factors (Oluyole and Sanusi, 2009). According to Villalobos (1989,), low yield, inconsistent crop production pattern, and use of simple tools have dampened returns from the venture. The implication of these is cocoa production reduction at a time when there are high cocoa demands as a result of increase growth in consumption of chocolate in the world Kamla, (2007). It has been stated that Nigeria was the first to liberalize cocoa export in terms of trade in West Africa, but it is discouraging to state that less is known about the nations' cocoa production performance (Wilcox and Abbot, 2004). However, Dandi (1991) reported that most post-harvest activities that generate better returns are still handled by multinationals participating in cocoa industry in Nigeria. The fall in percentage share of cocoa output may be attributable to two reasons, first is the negligence of the Agricultural sector by the past administrations due to the discovery of petroleum resources that now accounts for the enormity of foreign exchange and second is the endemic problem in the cocoa industry such as rising cost of production, price instability, and differences in management system. Against this background this study was embarked upon with the specific aims of:

i. identifying the socio-economic characteristic of the cocoa farmers in Abia State.

ii. determining which management system in cocoa production is more economically viable and profitable.

\section{METHODOLOGY}

The research was carried out in three Local Government Areas (L.G.A) of Abia State which are known to be the highest producer of cocoa in the state i.e. Bende, Ikwuano and Umuahia South L.G.As. Majority of cocoa producers are based in these selected L.G.As marking them out from the other L.G.As in terms of coca production. The instrument of data collection was a well structured questionnaire. A random selection technique was used in selecting 50 cocoa farmers from each of the three L.G.As. The data elicited from the farmers were three years data. A total of 150 cocoa farmers were selected for the study. The technique for data analyses included the use of descriptive statistic such as tables, frequency and percentages to analyse the socio-economic characteristics of the respondent. Net Present Value (NPV) and Benefit Cost Ratio (BCR) were used to determine the most viable management system in the study area. This estimating pattern is the most recent and has been used by other researchers including Nkang, (2006), who used in analyzing the most viable and profitable management systems of cocoa production in Cross State.

The Net Present Value (NPV) is an important decision making tools by investors in terms of viability indices. While benefit cost ratio is used to determine the profitability performance of a business, it is represented as follows:

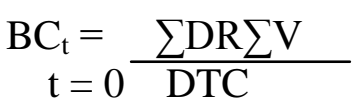

Where:

$\mathrm{DR} \sum \mathrm{V}=\quad$ Discounted revenue per farmer for an average of 3 years

$\mathrm{DTC}=$ Discounted total cost per farmer for an average of 3 years

$\mathrm{BCR}_{\mathrm{t}}=\quad$ Benefit cost ratio

NPV $=$ Present Value of Revenue - Present Value of Cost

\section{RESULTS AND DISCUSSION}

Table 1 presents socio-economic characteristics of cocoa farmers in Abia State. 
The socio-economic characteristic of the respondent selected for the study were analyzed with respect to the age, educational level, household size and farm size of cocoa farmers. The age composition of the farmers reveals that 4 percent of the farmers involved in lease management system were between the ages of 0-20 years. Also, 34\% farmers involved in owner management system, $10 \%$ in lease management system and $9 \%$ of the cocoa farmers in share crop management system were between the ages of $21-40$ years. Furthermore, $66 \%$ of owner managed farm farmers, $86 \%$ of lease managed farm farmers and $81 \%$ of share crop managed cocoa farm farmers were within the age range of 41 and above. It can be inferred from the aging scenario above that majority of the cocoa farmers were in their prime ages and were actively involved in cocoa production investment.

Table 1 Socio-economic characteristics of cocoa farmers in Abia State

\begin{tabular}{|c|c|c|c|c|c|c|}
\hline \multirow{2}{*}{ Variables } & \multicolumn{2}{|c|}{ Owner-managers } & \multicolumn{2}{|c|}{ Lease managers } & \multicolumn{2}{|c|}{ Share-crop managers } \\
\hline & Frequency & $\%$ & Frequency & $\%$ & Frequency & $\%$ \\
\hline \multicolumn{7}{|l|}{ Age: } \\
\hline $0-20$ & 0 & 0 & 2 & 4 & 0 & 0 \\
\hline $21-40$ & 17 & 34 & 5 & 10 & 7 & 9 \\
\hline 41 - above & 33 & 36 & 43 & 86 & 43 & 81 \\
\hline Total & 50 & 100 & 50 & 100 & 50 & 100 \\
\hline \multicolumn{7}{|l|}{ Educational Level: } \\
\hline No. formal Sch. & 3 & 6 & 4 & 8 & 2 & 5.6 \\
\hline Primary & 12 & 24 & 14 & 28 & 15 & 33.0 \\
\hline Secondary & 22 & 44 & 14 & 28 & 4 & 10.2 \\
\hline Secondary Incomplete & 0 & 18 & 11 & 22 & 10 & 19.6 \\
\hline Tertiary & 4 & 8 & 4 & 8 & 15 & 33.0 \\
\hline Tertiary Incomplete & 0 & 0 & 3 & 6 & 4 & 10.2 \\
\hline Total & 50 & 100 & $\mathbf{5 0}$ & 100 & 50 & 100 \\
\hline \multicolumn{7}{|l|}{ Household Size } \\
\hline $0-4$ & 12 & 24 & 13 & 26 & 17 & 36.6 \\
\hline $5-9$ & 31 & 42 & 25 & 50 & 16 & 33.3 \\
\hline $10-14$ & 13 & 26 & 7 & 14 & 12 & 23.3 \\
\hline 15 - above & 4 & 8 & 5 & 10 & 7 & 6.66 \\
\hline Total & 50 & 100 & $\mathbf{5 0}$ & 100 & 50 & 100 \\
\hline \multicolumn{7}{|l|}{ Farm Size: } \\
\hline $0-4$ & 9 & 18 & 5 & 10 & 12 & 30 \\
\hline $5-9$ & 26 & 52 & 25 & 50 & 18 & 43.3 \\
\hline $10-14$ & 15 & 30 & 20 & 40 & 13 & 26.6 \\
\hline Total & 50 & 100 & 50 & 100 & 50 & 100 \\
\hline \multicolumn{7}{|l|}{ Sources of fund } \\
\hline Personal savings & 12 & 64 & 33 & 66 & 26 & 70 \\
\hline Bank loans & 6 & 12 & 2 & 4 & 9 & 13.3 \\
\hline Informal loans & 12 & 24 & 15 & 30 & 10 & 16.6 \\
\hline Total & 50 & 100 & 50 & 100 & 50 & 100 \\
\hline
\end{tabular}

Source: Field Survey, 2009

The participation of majority of the active-aged people may be due to the fact that cocoa production activities require physical energy and is labour intensive. This was confirmed in a study by Adegeje and Ajayi (1996). Data on Educational level shows that the highest number of farmers without formal education were those under leased management, $8 \%$ of participant under this system have no formal education at all while $28 \%$ of them have attained primary and secondary levels education. The farmers operating under the owner managed system has the highest number of secondary education. By implication majority of the cocoa farmers 
attended secondary school as such were fairly educated. In his own opinion, Osun (2001) opined that higher level of education attaineded by the farmer not only increases their productivity but also enhances their ability to understand and utilize new technologies.

Majority of the cocoa farmers has household size varying from 5-9 members with respect to owner managed farms (42\%), lease managed (50\%) and $0-4$ for the share crop managers (36.6\%). The average family size is 7 members and this implied large household size. This finding found support in the report of preponderance of large family sizes among rural areas of Nigeria by Osun (2001). The farm size distributions of the farmers revealed that under the three management system majority of the plot sizes were within the range of $5-9$ hectares. Moreover, 30\% of the plots under owner managed system fall within $10-14$ hectares. While it was $40 \%$ for lease managed system and $26.6 \%$ for share crop system. These results hint that most cocoa farmer were small holders growing cocoa in less than 10 hectares of land as was confirmed in the study of Adeboye (2000). Results on sources of fund indicated that majority of the farmers in the three management systems funded their production from personal savings.

\section{Analyses of Benefit-Cost Ratio and Net Present Value of owner managed cocoa production system}

Table 2 presents the Benefit Cost Ratio and Net Present Value analyses of owner managed system of cocoa production per hectare at $10 \%$ discount rate.

Table 2: Benefit cost analysis for owner-managed farms

\begin{tabular}{lllllllll}
\hline S/N & $\begin{array}{l}\text { Yield } \\
\text { (ton) }\end{array}$ & $\begin{array}{l}\text { Price } \\
\text { (N/ton) }\end{array}$ & Revenue & $\begin{array}{l}\text { df } \\
\mathbf{1 0 \%}\end{array}$ & $\begin{array}{l}\text { at } \\
\text { Revenue }\end{array}$ & of & Cost & $\begin{array}{l}\text { PV } \\
\text { cost }\end{array}$ \\
\hline 1 & 2100 & 200 & 420000 & 0.909 & 381780 & 334000 & 303606 \\
2 & 800 & 180 & 144000 & 0.826 & 118944 & 85000 & 70210 \\
3 & 400 & 200 & 80000 & 0.751 & 60080 & 60000 & 45060 \\
4 & 550 & 200 & 110000 & 0.685 & 75350 & 92000 & 63020 \\
5 & 8400 & 200 & 168000 & 0.621 & 104328 & 132500 & 82282.5 \\
6 & 550 & 200 & 110000 & 0.534 & 58740 & 84800 & 45283.2 \\
7 & 550 & 200 & 110000 & 0.513 & 56430 & 90200 & 46272.6 \\
8 & 550 & 200 & 110000 & 0.467 & 51370 & 98200 & 45859.4 \\
9 & 550 & 200 & 110000 & 0.424 & 46640 & 124000 & 52576 \\
10 & 700 & 200 & 140000 & 0.386 & 54040 & 115200 & 44467.2 \\
11 & 900 & 200 & 180000 & 0.35 & 63000 & 142750 & 49962.5 \\
12 & 600 & 200 & 120000 & 0.319 & 38280 & 88600 & 28263.4 \\
13 & 1400 & 220 & 308000 & 0.29 & 89320 & 220600 & 63974 \\
14 & 550 & 150 & 82500 & 0.263 & 21697.5 & 78000 & 20514 \\
15 & 300 & 200 & 60000 & 0.239 & 14340 & 50000 & 11950 \\
16 & 800 & 200 & 160000 & 0.218 & 34880 & 121800 & 26552.4 \\
17 & 1000 & 250 & 250000 & 0.198 & 49500 & 175000 & 34650 \\
18 & 550 & 200 & 120000 & 0.18 & 21600 & 94200 & 16956 \\
19 & 550 & 200 & 110000 & 0.164 & 18040 & 88600 & 14530.4 \\
20 & 300 & 200 & 60000 & 0.149 & 8940 & 41800 & 6228.2 \\
21 & 700 & 200 & 140000 & 0.135 & 18900 & 100600 & 13581 \\
22 & 550 & 250 & 137500 & 0.122 & 16775 & 110100 & 13432.2 \\
23 & 700 & 220 & 154000 & 0.112 & 17248 & 120600 & 13507.2 \\
24 & 900 & 200 & 180000 & 0.102 & 18360 & 120000 & 12240 \\
25 & 800 & 200 & 160000 & 0.092 & 14720 & 125000 & 11500
\end{tabular}




\begin{tabular}{|c|c|c|c|c|c|c|c|}
\hline 26 & 700 & 200 & 140000 & 0.084 & 11760 & 110000 & 9240 \\
\hline 27 & 550 & 200 & 110000 & 0.076 & 8360 & 58000 & 4408 \\
\hline 28 & 700 & 200 & 140000 & 0.069 & 9660 & 72000 & 4968 \\
\hline 29 & 1200 & 180 & 216000 & 0.063 & 13608 & 132000 & 8316 \\
\hline 30 & 2100 & 200 & 420000 & 0.909 & 381780 & 334000 & 303606 \\
\hline 31 & 800 & 180 & 144000 & 0.826 & 118944 & 85000 & 70210 \\
\hline 32 & 400 & 200 & 80000 & 0.751 & 60080 & 60000 & 45060 \\
\hline 33 & 550 & 200 & 110000 & 0.685 & 75350 & 92000 & 63020 \\
\hline 34 & 8400 & 200 & 168000 & 0.621 & 104328 & 132500 & 82282.5 \\
\hline 35 & 300 & 200 & 60000 & 0.149 & 8940 & 41800 & 6228.2 \\
\hline 36 & 700 & 200 & 140000 & 0.135 & 18900 & 100600 & 13581 \\
\hline 37 & 550 & 250 & 137500 & 0.122 & 16775 & 110100 & 13432.2 \\
\hline 38 & 700 & 220 & 154000 & 0.112 & 17248 & 120600 & 13507.2 \\
\hline 39 & 900 & 200 & 180000 & 0.102 & 18360 & 120000 & 12240 \\
\hline 40 & 550 & 200 & 110000 & 0.467 & 51370 & 98200 & 45859.4 \\
\hline 41 & 550 & 200 & 110000 & 0.424 & 46640 & 124000 & 52576 \\
\hline 42 & 700 & 200 & 140000 & 0.386 & 54040 & 115200 & 44467.2 \\
\hline 43 & 900 & 200 & 180000 & 0.35 & 63000 & 142750 & 49962.5 \\
\hline 44 & 600 & 200 & 120000 & 0.319 & 38280 & 88600 & 28263.4 \\
\hline 45 & 550 & 200 & 110000 & 0.076 & 8360 & 58000 & 4408 \\
\hline 46 & 700 & 200 & 140000 & 0.069 & 9660 & 72000 & 4968 \\
\hline 47 & 1200 & 180 & 216000 & 0.063 & 13608 & 132000 & 8316 \\
\hline 48 & 2100 & 200 & 420000 & 0.909 & 381780 & 334000 & 303606 \\
\hline 49 & 800 & 180 & 144000 & 0.826 & 118944 & 85000 & 70210 \\
\hline 50 & 400 & 200 & 80000 & 0.057 & 4560 & 68000 & 3876 \\
\hline \multicolumn{3}{|c|}{ Total } & 4410000 & & 1501251 & $\mathbf{3 3 3 3 5 5 0}$ & 1167286.2 \\
\hline
\end{tabular}

The result above indicates a positive NPV of N333, 964.8 per hectare and estimated benefit cost ratio of 1.3 (at $10 \%$ discount rate) which is greater than one. This result implies that owner-managed cocoa production system is viable since the farmers can pay off the cost of the factors of production and still make some profits

\section{Analyses of Benefit-Cost Ratios and Net Present Values of Lease and Sharecrop managed cocoa production systems}

The total revenue which accrued from the lease and sharecrop managed cocoa production systems were $\mathrm{N} 4181900$ and N3991400. The costs of production for the two management systems were N2986840 and N2713700. Further, the benefit cost ratios of 1.4 and the net present values of N271236 and N303249 were recorded for both lease and sharecrop managed systems respectively. The calculated NPV value of N271.236 is positive and the lease management system of cocoa production is viable. The Benefit Cost Ratio for lease managed farm is 1.4 which is greater than unity, implying that the system is profitable. These positive and viable results are confirmed in the work of Nkang (2006). The result indicates that the NPV for share crop managed farms is positive and is estimated as N303, 249.1. The benefit cost ratio is estimated as 1.4. These results implied viability and profitability on the part of the sharecrop management system.

Considering the NPV figures of N333, 964.4, N300, 249 and N271, 236 for owner, sharecrop and lease cocoa management cocoa systems respectively. It is quite evident that the 
lease-management system is the least viable relative to owner-managed and share crop managed system. Also, with respect to BCR values of 1.3, 1.4 and 1.4 which are above unity for owner, sharecrop and lease management systems, implied profitable on the side of the systems.

\section{CONCLUSION}

The study examined the profitability and viability of three management systems of cocoa production in Abia State. This observed by from its empirical analyses that investment in cocoa production is viable and profitable. Also, relative to cost involved in cocoa production with respect to the three management systems, there were no much disparities. The management systems are practicable, efficient, viable and profitable. Investing in cocoa in the State even to the point rehabilitating abandoned old commercial farms is justifiable.

It is recommended that greater investment options should be explored in the Abia State in terms of cocoa production. Also, ample amount of capital therefore should be invested into cocoa production based on the outcome of the research to rehabilitate this dying and dwindling commercialized agricultural sector. Thus government and multinationals should assist the cocoa farmers with soft loans to encourage the farmers enhance production and break even.

\section{REFERENCES}

Ayorinde J. A., (1995): Historical Notes on the Introduction and development of cocoa industry in Nigeria. "Nigerian Agricultural Journal" No12 (6), pp 23-26.

Adegeye, A. J and W.O. Ajayi (1996), Cocoa Revolution in Nigeria. Adaptive Research Group Report. University of Ibadan, Pp 3-144

Erelu, O.O. (2008), Cocoa for and for Wealth. A paper presented in a Foruth Cocoa Day Celebrated in Osun State between $22^{\text {nd }}$ and $24^{\text {th }}$ April.

Osun T. (2001): Analysis of socio-economic factors affecting cocoa production in Ondo State case study of Idanre and Ondo East Local Government Area. B.Sc. Thesis in the department of Agricultural Economic and Extension, Federal University.

Oyinyole K. A and Usman J. M. (1999): Assessment of Economic Activities of Cocoa Liscenced buying agents (IBAS) in Odeda Local Government Area of Ogun State Nigeria Akoka Journal of Technology and science education 3(1): 130 - 140.

Oduwole O. O. (2004) Adoption of Improved Agronomic practices by cocoa farmers in Nigeria: A Multivariate Tobit Analysis Ph.D Thesis. Federal Unversity of Technology Nigeria.

Oluyelu, K.A. (2005), Evaluation of the Economics of Post Harvest Processing of Cocoa in Cross River State, Nigeria. Journal of Agriculture, Forestry and the Social Sciences. 3(2): 58-64

Oluyelu, K.A. and R. A Sanusi (2009) Socio-economic Variables and Cocoa Production in Cross River State, Nigeria. Journal of Human Ecology 25 (1): 5-8

Kama, Ray (2007): Socia-Economic variable of Cocoa production in Cross River State, Nigeria.

Nkang Moses (2006): Investment in cocoa production in Nigeria. A cost and return analysis of three cocoa production management systems in Cross River State cocoa belt. 